\title{
Model Luxury Brand dalam Menciptakan Purchase Intention
}

\author{
M.Ramadyanti ${ }^{1}$, L.A. Wibowo \& R. Purnama \\ Universitas Pendidikan Indonesia \\ mustikaramadyanti@student.upi.edu
}

\begin{abstract}
This research aims to determine the Effect of Luxury Brand on Purchase Intention iPhone X on member of the Indonesian iDevice Community. Type of this research is descriptive verification. Dependent variable of this research is purchase intention (Y), and luxury brand (X) as independent variable. The population are member of the Indonesian iDevice Community. This research uses a simple random sampling method and probability sampling techniques to 200 member. Data analysis technique using Structural Equation Modeling (SEM) with IBM SPSS AMOS version 24.0 for Windows. The findings of this research indicates that luxury brand and purchase intention are in good category. Luxury brand has a positive and significant influence on purchase intention. Extended self which is one of luxury brand's dimension gives the biggest contribution of purchase intention building.
\end{abstract}

Keywords: Luxury Brand, Purchase Intention

Article Type: Research Paper

Abstrak: Penelitian ini bertujuan untuk mengetahui Pengaruh Luxury Brand terhadap Purchase Intention iPhone $\mathrm{X}$ pada anggota komunitas iDecice Indonesia. Jenis penelitian yang digunakan adalah deskriptif verifikatif. Variabel terikat dalam penelitian ini adalah purchase intention (Y) serta luxury brand (X) sebagai variabel bebas. Populasi dalam penelitian ini anggota komunitas iDecice Indonesia. Pengambilan sampel dalam penelitian ini menggunakan metode simple random sampling dengan menggunakan teknik probability sampling terhadap 200 anggota komunitas. Teknik analisis yang digunakan adalah analisis Structural Equation Modeling (SEM) dengan alat bantu program IBM SPSS AMOS versi 24.0 for Windows. Hasil temuan penelitian ini menunjukan bahwa gambaran luxury brand terhadap purchase intention berada pada kategori baik. Luxury brand memiliki pengaruh yang positif dan signifikan terhadap purchase intention. Dimensi extended self dalam luxury brand memberi kontribusi yang paling besar dalam membentuk purchase intention.

Kata Kunci: Luxury Brand, Purchase Intention

Tipe Artikel: Studi Kasus

\section{PENDAHULUAN}

Minat beli seorang konsumen menjadi salah satu bagian penting yang diperhatikan perusahaan guna untuk memahami kebutuhan dan keinginan konsumen, dalam hubungannya dengan pembelian yang akan dilakukan (Wogalter, Kalsher, \& Litynski, 1996; Lee, Kim \& Leong, 2014; Chen, \& Lee, 2015). Perusahaan perlu mengidentifikasi keadaan yang memicu kebutuhan tersebut, sehingga perusahaan kemudian dapat menyusun strategi pemasaran yang dapat menimbulkan minat beli konsumen
(Pan, 2013 ; Kim \& Leong, 2014; Collange, 2015). Membangun minat beli konsumen telah menjadi tujuan utama bagi banyak perusahaan, karena akan menciptakan tingkat probabilitas yang lebih tinggi untuk mendapatkan keunggulan kompetitif dibandingkan dengan perusahaan pesaing lainnya (Lassar, Mittal, \& Sharma, 1995; Das, 2017).

Minat beli merupakan konsep penting dalam bisnis yang berkembang dalam 30 tahun terakhir dan telah muncul sebagai salah satu isu penting yang dibahas dan dipahami dalam 
pemasaran (Wang, Wiegerinck, Krikke, \& Zhang, 2013). Konsep minat beli merupakan bagian dari komponen perilaku konsumen (Bedi, 2017). Seorang konsumen pada saat akan melakukan pembelian pasti didasari oleh keinginan dan kebutuhannya (Khan \& Rahman, 2014). Minat beli timbul setelah adanya proses evaluasi alternatif, dalam proses tersebut konsumen akan membuat suatu rangkaian pilihan mengenai produk yang hendak dibeli atas dasar merek maupun minat (Echo Huang, 2012; Ko, 2017).

Penelitian mengenai konsep minat beli telah dilakukan dalam beberapa industri mulai dari industri olahraga (Liu, 2011), industri restoran (Mccall \& Lynn, 2015), industri otomotif (Jalilvand \& Samiei, 2012), industri hotel (Chiang \& Jang, 2008), industri smartphone (Phau \& Teah, 2009).

Smartphone menjadi salah satu perangkat komunikasi yang turut mengalami perkembangan seiring kemajuan teknologi informasi (Haba, 2017). Smartphone telah berkembang menjadi salah satu produk yang sangat dibutuhkan karena perannya dalam membantu kelancaran aktivitas sehari-hari, halini ditandai dengan pesatnyapenetrasi produsen smartphone di Indonesia. Berbagai strategi dilakukan oleh perusahaan smartphone agar mampu merebut konsumen, diantaranya dengan menawarkan harga yang terjangkau, kemewahan, dan kualitas produk yang baik. Menyasar segmen pasar yang tepat, menjadi salah satu kunci kesuksesan perusahan smartphone untuk bertahan di industri smartphone Indonesia (Agrebi \& Jallais, 2015).

Di Indonesia sendiri, pengguna smartphone memiliki trend yang cenderung meningkat tiap tahunnya. Respon masyarakat yang sangat tinggi terhadap perangkat smartphone membuat perusahaan-perusahaan yang bergerak di bidang industri smartphone bersaing untuk menghasilkan produk yang berbeda dengan yang lainnya (Favre, 2007). Besarnya potensi pasar smartphone Indonesia menjadi daya tarik tersendiri bagi para vendor ponsel dunia. Bahkan indonesia menjadi surga bagi para produsen asing seperti Eropa, Amerika Serikat, Jepang, Korea Selatan, hingga Cina terus membanjiri produk-produk terbarunya (Gana \& Koce, 2016).
Pada era global telah mengubah keperluan konsumen tentang peralatan telekomunikasi, semakin banyak inovasi yang memfasilitasi kegiatan publik. Sejalan dengan pertumbuhan pasar (El-baz, 2016), Indonesia sebagai salah satu negara berkembang merupakan pasar smartphone yang sangat besar. Indonesia bahkan pernah menjadi pasar smartphone terbesar di Asia Tenggara. Ponsel pintar adalah salah satu teknologi yang tumbuh paling cepat dari tahun ke tahun. Banyak produsen smartphone yang sedang berkembang untuk menciptakan produk-produk perusahaan kualitas terbaik (Phau \& Teah, 2009).

Industri smartphone berlomba-lomba untuk memberikan inovasi dan kecanggihan terhadap produk yang dihasilkan. Semakin berkembangnya teknologi, fitur-fitur yang ada di smartphone semakin banyak dan beragam jenisnya (Azira, Zaharah, Kuan, Abas, \& Meriam, 2016). Fitur-fitur andalan di setiap merk smartphone berbeda-beda, mulai dari yang mengedepankan kecepatan multitasking untuk para penggunanya dan sampai yang mengandalkan fitur kecanggihan di kameranya, oleh karena itu berbagai merk smartphone bersaing keras untuk menarik minat pembeli (Chen, 2018).

Kebutuhan akan smartphone sekarang semakin besar tidak hanya untuk memenuhi akan kebutuhan konsumennya, tetapi juga menjadi simbol kemewahan dan trend semata (Agrebi \& Jallais, 2015). Saat ini persaingan di bisnis industri smartphone semakin ketat, para produsen melakukan banyak hal untuk menarik minat membeli konsumennya. Para produsen pun tidak segan untuk melakukan perang harga untuk menaikan penjualaannya (Ardelia, 2017).

Persaingan dalam industri smartphone mendorong para pengusaha untuk memunculkan pemikiran-pemikiran baru yang dapat membangun produk yang memberikan nilai lebih kepada pelanggan (Bian \& Forsythe, 2012; Plavini Punyatoya, 2015). Kecermatan para pebisnis dalam menyesuaikan produk sesuai dengan kebutuhan masyarakat menjadi salah satu faktor penentu keberhasilan suatu bisnis dalam bertahan (Sujata et al., 2015). Dengan demikian, hanya perusahaan yang berkualitas yang mampu untuk bersaing dan menguasai pasar agar 
minimbulkan minat beli dari konsumen pada industri smartphone

Minat beli berdampak terhadap konsumen maupun perusahaan (Chiang \& Jang, 2008). Bagi konsumen minat beli merupakan salah satu tahap penting sebelum mengambil keputusan pembelian untuk memenuhi keinginan dan kebutuhannya. Setelah adanya minat beli maka akan berujung kepada keputusan pembelian, apabila konsumen merasakan kepuasan atas produk yang dibeli maka konsumen akan

\section{METODE PENELITIAN}

Metode penelitian yang digunakan adalah metode explanatory survey. Explanatory survey dilakukan untuk mengeksplorasi situasi masalah, yaitu untuk mendapatkan ide-ide dan wawasan kedalam masalah yang dihadapi manajemen atau para peneliti tersebut.

Populasi dalam penelitian ini adalah anggota komunitas iDevice Indonesia. Total anggota komunitas iDevice Indonesia sebanyak 20.546 orang yang tergabung dalam komunitas tersebut.

Dalam penelitian ini adalah teknik probability sampling yaitu simple random sampling dengan jumlah sampel sebanyak 200 responden. Teknik pengumpulan data yang digunakan adalah studi kepustakaan, studi lapangan dengan penyebaran kuesioner, dan studi literatur. Sedangkan teknik analisis data yang dilakukan adalah analisis deskriptif menggunakan distribusi frekuensi.

Penelitian ini meneliti pengaruh luxury brand (X) terhadap purchase intention (Y). Variabel bebas (independent variable) atau variabel eksogen yang terdapat pada penelitian ini yaitu luxury brand dengan dimensi conspicuousness, uniqueness, quality, hedonic dan extended self. Sedangkan variabel terikat (dependent variable) atau variabel endogen pada penelitian ini yaitu purchase intention dengan dimensi transaksional, refrensial, prefrensial dan eksploratif.

\section{HASIL DAN PEMBAHASAN}

Teknik analisis SEM memiliki beberapa asumsi yang harus dipenuhi, terdiri dari ukuran sampel, normalitas data, ouliers data, dan multikolinieritas. SEM memiliki beberapa asumsi dasar yang harus dipenuhi sebelum menguji pengaruh model penelitian, guna mengetahui apakah pengujian model dapat melakukan pembelian ulang yang menyebabkan loyalitas kepada perusahaan (Das, 2017). Maka paradigma penelitian ini adalah:

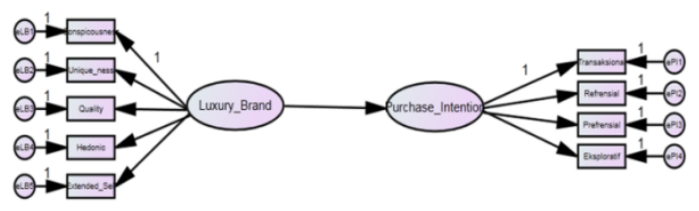

\section{Gambar 1. Paradigma Penelitian}

dilanjutkan atau tidak. Asumsi dasar tersebut antara lain ukuran sampel,

\section{A. Uji Asumsi SEM}

normalitas data, outliers data dan multikolinearitas. Pada penelitian ini, seluruh asumsi dasar SEM terpenuhi sehingga dapat dikatakan bahwa data dapat diproses lebih jauh untuk dilakukan analisis SEM.

\section{Ukuran Sampel}

Ukuran sampel yang harus dipenuhi dalam SEM adalah minimal berukuran 100. Ukuran sampel memberikan dasar untuk mengestimasi sampling error. Sampel dalam penelitian ini berjumlah 200, maka penelitian ini menggunakan estimasi Maximum Likelihood dikarenakan model estimasi ML mampu tahan terhadap data non formal.

\section{Normalitas Data}

Sebaran data harus dianalisis melalui uji normalitas untuk melihat apakah asumsi normalitas dipenui sehingga data dapat diolah lebih lanjut untuk pemodelan (Hair, et al., 2014). Apabila distribusi data mampu membentuk sebaran yang normal, maka normalitas data tersebut terpenuhi (Sarjono \& Julianita, 2015).

Syarat untuk data berdistribusi normal dinyatakan dengan kriteria skewness critical ratio value (kemencengan) yang dihasilkan sebesar harus lebih kecil sama dengan $(\leq)$ 2,58,atau berada pada rentang $\pm 2,58$. Ghozali (2014) memaparkan bahwa asumsi normalitas harus terpenuhi secara multivariate normal sebagai konsekuensi jumlah sampel yang besar dan penggunaan metode estimasi ML, dengan syarat critical ratio multivariate nilainya berada di bawah 2,58 (Mardia, 1970). Tabel 1. Hasil Uji Normalitas Data diperoleh nilai skewness 
TABEL 1.

HASIL UJI NORMALITAS DATA

\begin{tabular}{ccccccc}
\hline Variable & min & max & skew & c.r. & kurtosis & c.r. \\
\hline Extended_Self & 14 & 21 & -0.320 & -1.848 & -0.414 & -1.196 \\
Hedonic & 18 & 28 & -0.203 & -1.171 & -0.641 & -1.850 \\
Quality & 18 & 28 & -0.253 & -1.459 & -0.302 & -0.871 \\
Unique_ness & 24 & 35 & -0.249 & -1.435 & -0.093 & -0.269 \\
Eksploratif & 13 & 21 & -0.133 & -0.767 & -0.501 & -1.447 \\
Prefrensial & 14 & 21 & -0.022 & -0.128 & -0.667 & -1.926 \\
Refrensial & 13 & 21 & -0.361 & -2.084 & -0.440 & -1.270 \\
Transaksional & 18 & 28 & -0.353 & -2.039 & -0.641 & -1.851 \\
Conspicousness & 19 & 28 & -0.051 & -0.296 & -0.742 & -2.143 \\
\hline Multivariate & & & & & 3.523 & 1.770 \\
\hline
\end{tabular}

Sumber: Hasil Pengolahan Data, 2019.

(Menggunakan Software IBM SPSS AMOS versi 24.0 for Windows)

\section{Outlier Data}

Outlier adalah kondisi observasi dari suatu data yang memiliki karakteristik unik yang terlihat sangat berbeda jauh dari observasi lainnya dan muncul dalam bentuk nilai ekstrim baik untuk sebuah variabel tunggal ataupun variabel-variabel kombinasi (Hair.et. al, 2010 ; $34)$. a. Evaluasi Univeriate Outlier

Untuk menditeksi ada tidaknya univariate outlier pada data dilihat berdasarkan standar score atau Z-score yang mempunyai nilai rata-rata nol dengan standar deviasi sebesar 1.00. Observasi data memiliki nilai $\mathrm{Z}$ score $\geq \pm 4.0$ akan dikategorikan sebagai univariate outlier untuk sampel yang berukuran besar (Hair.et. al, $2010 ; 65)$.

TABEL 2

HASIL OUTLIERS DATA DIMENSI

\begin{tabular}{|l|r|r|r|r|r|}
\hline & $\mathrm{N}$ & Minimum & Maximum & \multicolumn{1}{l|}{ Mean } & Std. Deviation \\
\hline ZConspicousness & 200 & -2.21039 & 2.24006 & .0000000 & 1.00000000 \\
\hline ZUniqueness & 200 & -2.40985 & 2.36643 & .0000000 & 1.00000000 \\
\hline ZQuality & 200 & -2.50415 & 2.00784 & .0000000 & 1.00000000 \\
\hline ZHedonic & 200 & -2.37522 & 2.01521 & .0000000 & 1.00000000 \\
\hline ZExtended_Self & 200 & -2.48791 & 1.78580 & .0000000 & 1.00000000 \\
\hline ZTransaksional & 200 & -2.09826 & 1.60564 & .0000000 & 1.00000000 \\
\hline ZRefrensial & 200 & -2.37693 & 1.70363 & .0000000 & 1.00000000 \\
\hline ZPrefrensial & 200 & -2.06960 & 1.94904 & .0000000 & 1.00000000 \\
\hline ZEksploratif & 200 & -2.48684 & 1.91952 & .0000000 & 1.00000000 \\
\hline Valid N (listwise) & 200 & & & & \\
\hline
\end{tabular}

Sumber: Hasil Pengolahan Data, 2019.

(Menggunakan Software IBM SPSS AMOS versi 24.0 for Windows)

Berdasarkan hasil pengolahan data yang dilakukan nilai Z-Score maksimum sebesar 2.36643 dan nilai minimum terkecil adalah 2.50415. Hasil yang diperoleh menunjukkan tidak terdapat univariate outlier karena nilai ZScore kecil dari \pm 4.0. Hasil perhitungan dapat dilihat pada lampiran Evaluasi Univeriate Outlier.

\section{b. Evaluasi Multivariate Outlier}

Evaluasi terhadap Multivariate outlier perlu dilakukan karena pada data yang dianalisis menunjukkan adanya outlier pada tingkat univariate. Untuk mendeteksi ada tidaknya multivariate outlier dilakukan dengan 
memperhatikan nilai mahalanobis (The Mahalanobis Distance).

Model peneltian yang digunakan terdiri atas 9 variabel observed (total indikator X dan Y). Jarak Mahalanobis (Mahalanobis Distance) dihitung berdasarkan nilai Chi-Square pada derajat bebas sebesar 9 (jumlah variabel manifest/ observed) pada tingkat signifikansi $\mathrm{p}<0,001$.

Nilai Cutt of untuk Mahalanobis distance berdasarkan $\chi^{2}(9 ; 0,001)$ diperoleh sebesar 27,877 (berdasarkan tabel distribusi $\chi^{2}$ ). Jadi data yang memiliki jarak mahalanobis lebih besar dari 27,877 termasuk dalam kreteria multivariate outlier.

Hasil perhitungan mahalanobis outlier terbesar pada penelitian ini diperoleh nilai sebesar 20,660 yang dapat dilihat dalam lampiran output perhitungan multivariate outlier. Oleh karena tidak ada nilai mahalanobis yang lebih dari 27,877 maka dapat disimpulkan tidak

\section{B. Pengujian SEM}

1. Spesifikasi (Model Spesification)

Tahap ini berkaitan dengan pembentukan model awal persamaan struktural, sebelum dilakukan estimasi. Model awal ini diformulasikan berdasarkan suatu teori atau penelitian sebelumnya. Model awal pada penelitian ini tergambar sebagai berikut :

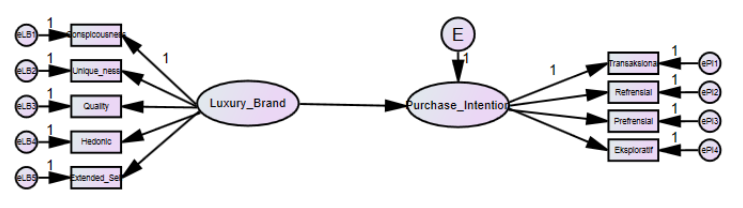

Sumber: Hasil Pengolahan Data, 2019. (Menggunakan Software IBM

SPSS AMOS versi 22.0 for Windows)

GAMBAR 2 SPESIFIKASI MODEL

Selanjutnya berdasarkan model yang dibuat, maka data yang telah melalui tahapan pengujian asumsi dasar digunakan untuk terdapat Multivariate outlier pada data hasil penelitian.

\section{Multikolinearitas}

Penilaian atau evaluasi atas Multikolinearitas dan Singularitas pada data yang digunakan dilakukan untuk melihat apakah pada data penelitian terdapat multikolineritas (multicollinearity) atau singularitas (singularity) dalam kombinasi-kombinasi variabel. Untuk menilai Multikolinearitas dan Singularitas dilakukan dengan melihat determinan dari matriks kovarians sampelnya. Adanya multikolineritas dan singularitas dapat diketahui melalui nilai determinan matriks kovarians yang benar-benar kecil, atau mendekati nol (Tabachnick \& Fidell, 2013; 689).

Berdasarkan hasil pengolahan data diperoleh nilai determinan matriks kovarians sampel (Determinant of sample covariance matrix $)=8493.731$. Dapat dikatakan bahwa Tidak terdapat multikolineritas dan singularitas pada data penelitian yang digunakan.

pengujian model SEM. Data terdiri dari 200 sampel dengan jumlah 33 item pertanyaan, 20 item untuk pertanyaan variabel Luxury Brand dan 13 item untuk pertanyaan variabel Purchase Intention.

Selanjutnya berdasarkan model yang dibuat, maka data yang telah melalui tahapan pengujian asumsi dasar digunakan untuk pengujian model SEM. Data terdiri dari 200 sampel dengan jumlah 33 item pertanyaan, 20 item untuk pertanyaan variabel Luxury Brand dan 13 item untuk pertanyaan variabel Purchase Intention.

\section{Identifikasi (Identification)}

Tahap ini berkaitan dengan pengkajian tentang kemungkinan diperolehnya nilai yang unik untuk setiap parameter yang ada di dalam model dan kemungkinan persamaan simultan tidak ada solusinya.

Berdasarkan hasil pengolahan data menggunakan software AMOS versi 24 for windows diperoleh perhitungan derajat bebas (degree offreedom/df) untuk model SEM sebagai berikut. 


\section{TABEL 3}

HASIL IDENTIFIKASI

\begin{tabular}{|cc|}
\hline $\begin{array}{c}\text { Notes for Model (Default model) } \\
\text { Computation of degrees of freedom (Default model) }\end{array}$ \\
\hline Number of distinct sample moments: & 45 \\
\hline Number of distinct parameters to be estimated: & 19 \\
Degrees of freedom (45 - 19): & 26 \\
\hline
\end{tabular}

Sumber: Hasil Pengolahan Data, 2019.

(Menggunakan Software IBM SPSS AMOS versi 24.0 for Windows)

Pada penelitian ini nilai derajat bebas (degree of freedom/df) untuk model SEM yang digunakan diperoleh adalah 25. Nilai derajat bebas menunjukkan angka positif sehingga dapat dikatakan identifikasi pada model penelitian ini adalah over identified yang memungkinkan estimasi dan penilaian model dapat dilakukan lebih lanjut.

\section{Estimasi (Estimation)}

Tahap ini berkaitan dengan estimasi terhadap model untuk menghasilkan nilai-nilai parameter dengan menggunakan salah satu metode estimasi yang tersedia. Pada penelitian ini karena data sampel berukuran 200 responden memenuhi distribusi data normal, maka estimasi yang digunakan adalah Maximum Likehood Estimation. Tabel 4 menunjukkan hasil uji Estimasi Measurement Model.

TABEL 4

\section{HASIL PERHITUNGAN LODING FAKTOR ESTIMASI MEASUREMENT MODEL}

\begin{tabular}{|c|c|c|c|c|c|}
\hline Dimensi & & Variabel & Estimate & C.R. & $\mathrm{P}$ \\
\hline Transaksional & $\begin{array}{l}<- \\
- \\
<-\end{array}$ & Purchase_Intention & 0.687 & - & - \\
\hline Eksploratif & $\begin{array}{l}-- \\
<-\end{array}$ & Purchase_Intention & 0.718 & 8.603 & 0.000 \\
\hline Prefrensial & $\begin{array}{l}-- \\
<-\end{array}$ & Purchase_Intention & 0.776 & 9.093 & 0.000 \\
\hline Refrensial & $\begin{array}{l}-- \\
<-\end{array}$ & Purchase_Intention & 0.681 & 8.134 & 0.000 \\
\hline Conspicousness & $\begin{array}{l}-- \\
<-\end{array}$ & Luxury_Brand & 0.727 & - & - \\
\hline Extended_Self & $\begin{array}{l}-- \\
<-\end{array}$ & Luxury_Brand & 0.746 & 9.690 & 0.000 \\
\hline Quality & $\begin{array}{l}-- \\
<-\end{array}$ & Luxury_Brand & 0.774 & 10.075 & 0.000 \\
\hline Hedonic & $\begin{array}{l}-- \\
<-\end{array}$ & Luxury_Brand & 0.715 & 9.568 & 0.000 \\
\hline Unique_ness & -- & Luxury_Brand & 0.747 & 9.810 & 0.000 \\
\hline
\end{tabular}

Sumber: Hasil Pengolahan Data, 2019.

(Menggunakan Software IBM SPSS AMOS versi 24.0 for Windows)

Setelah dilakukan perhitungan model penelitian diperoleh nilai loading factor seluruh dimensi (variabel manifes) variabel Luxury
Brand (X) dan Purchase Intention (Y) sudah di atas rata-rata cut off (batas) untuk loding faktor yang baik (disarankan) sebesar 0,5. Loading 
factor dengan hasil tertinggi yaitu indikator Prefrensial dalam membentuk Purchase Intention dengan nilai sebesar 0,776, hasil terendah ditunjukkan oleh indicator Refrensial dalam membentuk Purchase Intention dengan nilai sebesar 0,681. Nilai $t_{\text {hitung }}$ (CR/Critical Ratio) yang diperoleh untuk setiap loding faktor dari dimensi variabel laten Luxury Brand (X) dan Purchase Intention (Y) lebih dari 1,96 sehingga dapat dikatakan bahwa variabel manifes yang digunakan bermakna (signifkan) dalam mengukur variabel Luxury Brand (X) dan Purchase Intention (Y).

Hasil pengujian estimasi measurement model menunjukkan seluruh Dimensi dan konstruk valid $(>0,5)$ maka pengujian dapat dilakukan ke tahap berikutnya yaitu pengujian structural model melalui uji kecocokan (testing fit).

\section{Uji Kecocokan (Testing Fit)}

Uji kecocokan keseluruhan model dilakukan untuk mengevaluasi secara umum derajat kecocokan atau Goodness of Fit (GOF) antara data dengan model, validitas dan reliabilitas model pengukuran, dan signifikansi koefisien-koefisien dari model struktural. Uji kecocokan dilakukan melalui beberapa tahap yaitu kecocokan model pengukuran, kecocokan model structural dan kecocokan keseluruhan model.

\section{Kecocokan Model Pengukuran (Measurement Model Fit)}

Kecocokan model pengukuran dilakukan terhadap setiap konstruk (hubungan antara variabel laten dengan beberapa variabel teramati/dimensi) secara terpisah melalui evaluasi terhadap validitas dan reliabilitas dari model pengkuran.

a. Konstruk Eksogen Luxury Brand (LB) Berdasarkan Gambar 4.2 dapat dilihat bahwa model pengukuran konstruk eksogen Luxury Brand secara keseluruhan fit, memiliki nilai goodness of fit yang baik karena memiliki nilai $P$-value (prob) $=0,185>0,05$, nilai RMSEA $0,050<0,08$ serta nilai TLI, CFI, GFI dan AGFI yang lebih besar daripada 0,9 .

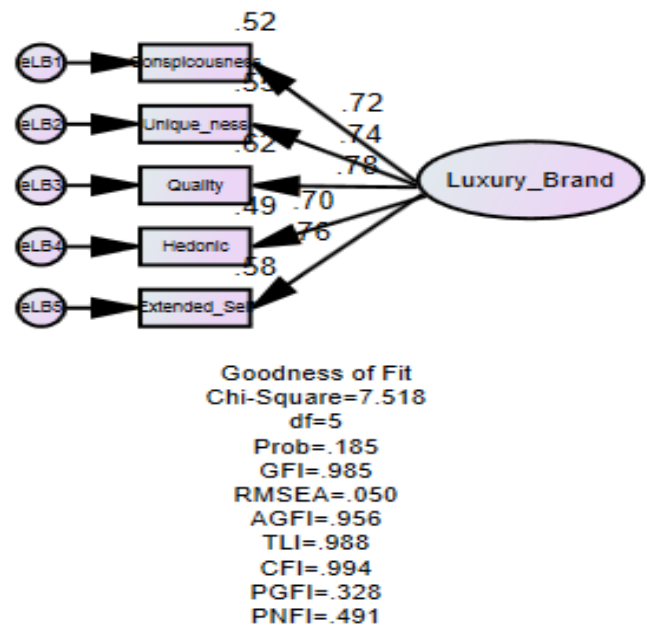

Sumber: Hasil Pengolahan Data, 2019. (Menggunakan Software IBM SPSS AMOS versi 24.0 for Windows)

GAMBAR 3

MODEL PENGUKURAN KONSTRUK EKSOGEN LUXURY BRAND

Hasil pengujian validitas dan reliabilitas model pengukuran konstruk eksogen Luxury Brand (LB) disajikan dalam tabel berikut:

MODEL PENGUKURAN KONSTRUK EKSOGEN LUXURY BRAND (LB)

\begin{tabular}{|c|c|c|c|c|c|c|c|c|c|}
\hline & & & \multicolumn{2}{|c|}{ Estimate } & \multirow[b]{2}{*}{ S.E. } & \multirow[b]{2}{*}{ C.R. } & \multirow[b]{2}{*}{$P$} & \multirow{2}{*}{$\begin{array}{c}\text { Variance } \\
\text { Extract } \\
(\geq 0.50)\end{array}$} & \multirow{2}{*}{$\begin{array}{c}\text { Construct } \\
\text { Reliability } \\
(\geq 0.70)\end{array}$} \\
\hline & & & $R W$ & $S R W$ & & & & & \\
\hline Conspicousness & $<--$ & Luxury_Brand & 1.000 & 0.722 & & & & & \\
\hline Unique_ness & $<--$ & Luxury_Brand & 1.166 & 0.739 & 0.123 & 9.518 & $* * *$ & & \\
\hline Quality & $<--$ & Luxury_Brand & 1.191 & 0.784 & 0.120 & 9.889 & $* * *$ & 0,550 & 0,859 \\
\hline Hedonic & $<--$ & Luxury_Brand & 1.095 & 0.702 & 0.118 & 9.25 & $* * *$ & & \\
\hline Extended_Self & $<--$ & Luxury_Brand & 0.852 & 0.759 & 0.089 & 9.563 & $* * *$ & & \\
\hline
\end{tabular}

RW $=$ Regression Weights

SRW $=$ Standardized Regression Weights

Sumber: Hasil Pengolahan Data, 2019. 
(Menggunakan Software IBM SPSS AMOS versi 24.0 for Windows)

Berdasarkan tabel diatas diketahui nilai loading factor yang distandarkan (SRW) untuk masing-masing dimensi lebih dari 0.5 sehingga dapat dikatakan bahwa dimensi Conspicousness, Extended Self, Quality, Hedonic, dan Unique ness memiliki validitas yang baik dalam mengukur variabel Luxury Brand (LB).

Pengukuran reliabilitas model pengukuran konstruk eksogen Luxury Brand (LB) digunakan dua ukuran yaitu Construct Reliability (CR) dan Variance Extract (VE). Menurut Hair et al (2006; 777) sebuah konstruk mempunyai reliabilitas yang baik jika nilai CRnya $\geq 0,70$ dan nilai $V E$-nya $\geq 0,50$.

Berikut ini merupakan perhitungan variance extract (VE) dan construct reliability (CR) yang terdapat pada Tabel 4.22

$$
\begin{aligned}
\text { Variance Extracted } & =\frac{\sum \lambda i^{2}}{n} \\
& =\frac{2,752}{5}=0,550
\end{aligned}
$$

Construct Reliability $=\frac{\left(\sum \lambda i\right)^{2}}{\left(\sum \lambda i\right)^{2}+\left(\sum \delta i\right)}$

$$
\begin{aligned}
& =\frac{13,734}{13,734+2,248} \\
& =\frac{13,734}{15,982}=0,859
\end{aligned}
$$

Keterangan:

$\sum \lambda=$ standardized loading untuk tiap-tiap dimensi (SRW)

$\sum \delta \mathrm{i}=$ measurement error dari setiap dimensi $\left(1-\lambda^{2}\right)$

Berdasarkan perhitungan diatas dapat dilihat bahwa nilai $\mathrm{VE}=0,550 \geq 0,50$ dan nilai $\mathrm{CR}=0,859 \geq 0,70$ sehingga dapat dikatakan bahwa konstruk memiliki reliabilitas yang baik.

\section{b. Konstruk Endogen Purchase Intention (PI)}

Berdasarkan Gambar 4.4 dapat dilihat bahwa model pengukuran konstruk eksogen Purchase Intention secara keseluruhan fit, memiliki nilai goodness of fit yang baik karena memiliki nilai $P$-value (prob) $=0,508>0,05$, nilai RMSEA $0,000<0,08$ serta nilai TLI, CFI, GFI dan AGFI yang lebih besar daripada 0,9.

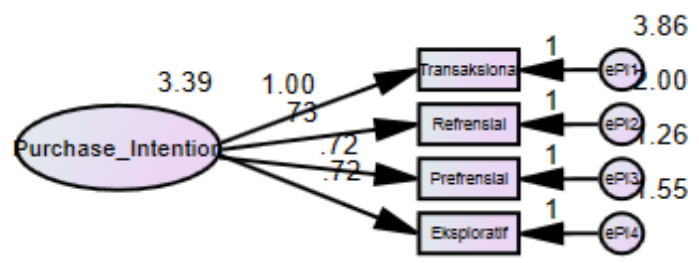

$$
\begin{gathered}
\text { Goodness of Fit } \\
\text { Chi-Square }=1.354 \\
\text { df }=2 \\
\text { Prob }=.508 \\
\text { GFI }=.997 \\
\text { RMSEA }=.000 \\
\text { AGFI }=.983 \\
\text { TLI }=1.008 \\
\text { CFI }=1.000 \\
\text { PGFI }=.199 \\
\text { PNFI }=.332
\end{gathered}
$$

\begin{tabular}{|c|c|c|c|c|c|c|c|c|c|}
\hline & & & \multicolumn{2}{|c|}{ Estimate } & \multirow[b]{2}{*}{ S.E. } & \multirow[b]{2}{*}{ C.R. } & \multirow[b]{2}{*}{$P$} & \multirow{2}{*}{$\begin{array}{c}\text { Variance } \\
\text { Extract } \\
(\geq 0.50)\end{array}$} & \multirow{2}{*}{$\begin{array}{c}\text { Construct } \\
\text { Reliability } \\
(\geq 0.70)\end{array}$} \\
\hline & & & $\boldsymbol{R} \boldsymbol{W}$ & $S R W$ & & & & & \\
\hline Transaksional & $<---$ & Purchase Intention & 1.000 & 0.684 & & & & \multirow{4}{*}{0,514} & \multirow{4}{*}{0,736} \\
\hline Refrensial & $<--$ & Purchase_Intention & 0.733 & 0.690 & 0.093 & 7.847 & $* * *$ & & \\
\hline Prefrensial & $<---$ & Purchase_Intention & 0.720 & 0.763 & 0.084 & 8.599 & $* * *$ & & \\
\hline Eksploratif & $<--$ & Purchase_Intention & 0.715 & 0.727 & 0.086 & 8.274 & $* * *$ & & \\
\hline
\end{tabular}

Sumber: Hasil Pengolahan Data, 2019. (Menggunakan Software IBM SPSS AMOS versi 24.0 for Windows)

\section{GAMBAR 4 \\ MODEL PENGUKURAN KONSTRUK EKSOGEN PURCHASE INTENTION}

Hasil pengujian validitas dan reliabilitas model pengukuran konstruk eksogen Purchase Intention (PI) disajikan dalam tabel berikut:

\section{TABEL 6}

MODEL PENGUKURAN KONSTRUK EKSOGEN PURCHASE INTENTION (PI)

$\mathrm{RW}=$ Regression Weights

SRW = Standardized Regression Weights 
Sumber : Hasil Pengolahan Data, 2019

Sumber: Hasil Pengolahan Data, 2019.

(Menggunakan Software IBM SPSS AMOS versi 24.0 for Windows)

Berdasarkan tabel diatas diketahui nilai loading factor yang distandarkan (SRW) untuk masing-masing dimensi lebih dari 0.5 sehingga dapat dikatakan bahwa dimensi Transaksional, Eksploratif, Prefrensial dan Refrensial memiliki validitas yang baik dalam mengukur variabel Purchase Intention (PI).

Pengukuran reliabilitas model pengukuran konstruk eksogen Purchase Intention (LB) digunakan dua ukuran yaitu Construct Reliability (CR) dan Variance Extract (VE). Menurut Hair et al (2006 ; 777) sebuah konstruk mempunyai reliabilitas yang baik jika nilai CRnya $\geq 0,70$ dan nilai $V E$-nya $\geq 0,50$.

Berikut ini merupakan perhitungan variance extract (VE) dan construct reliability (CR) yang terdapat pada Tabel 4.22

$$
\begin{aligned}
\text { Variance Extracted } & =\frac{\sum \lambda i^{2}}{n} \\
& =\frac{2,056}{5}=0,514
\end{aligned}
$$

$$
\begin{aligned}
\text { Construct Reliability } & =\frac{\left(\sum \lambda i\right)^{2}}{\left(\sum \lambda i\right)^{2}+\left(\sum \delta i\right)} \\
& =\frac{8,202}{8,202+2,935} \\
& =\frac{8,202}{11,137}=0,736
\end{aligned}
$$

Keterangan:

$\sum \lambda=$ standardized loading untuk tiap-tiap dimensi (SRW)

$\sum \delta \mathrm{i}=$ measurement error dari setiap dimensi $\left(1-\lambda^{2}\right)$

Berdasarkan perhitungan diatas dapat dilihat bahwa nilai $\mathrm{VE}=0,514 \geq 0,50$ dan nilai
$\mathrm{CR}=0,736 \geq 0,70$ sehingga dapat dikatakan bahwa konstruk memiliki reliabilitas yang baik.

\section{Kecocokan Model Struktural (Structural Model Fit)}

Analisis model struktural berhubungan dengan evaluasi terhadap parameter-parameter yang menunjukkan hubungan kausal atau pengaruh satu variabel laten terhadap variabel laten lainnya.

Berikut ini disajikan gambar parameter estimasi standardized loading factor model struktural. Struktur model Luxury Brand terhadap Purchase Intention setelah dilakukan uji goodness of fit terlihat pada Gambar 4.5 Struktur Model Luxury Brand terhadap Purchase Intention berikut ini:

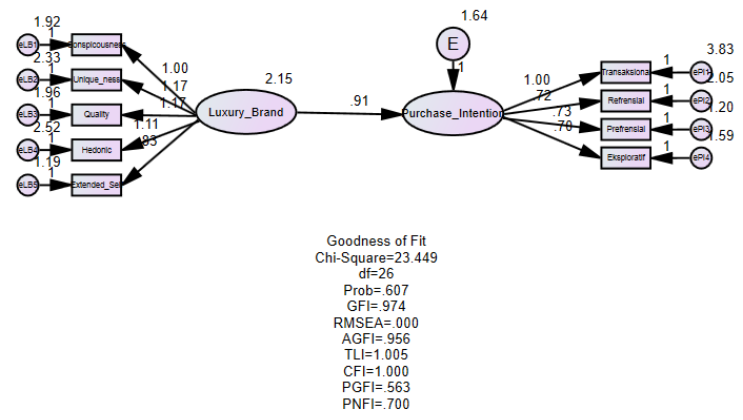

Sumber: Hasil Pengolahan Data, 2019. (Menggunakan Software IBM SPSS AMOS versi 24.0 for Windows)

GAMBAR 5

STRUKTUR MODEL LUXURY BRAND TERHADAP PURCHASE INTENTION

Berdasarkan gambar 4.6 dapat diketahui nilai estimasi parameter dari variabel yang digunakan disajikan dalam Tabel 7 berikut.

TABEL 7

HASIL ESTIMASI PARAMETER MODEL MODEL LUXURY BRAND TERHADAP PURCHASE INTENTION

\begin{tabular}{ccccccccc}
\hline & Model & & \multicolumn{2}{c}{ Estimate* $^{*}$} & $\boldsymbol{S E}$ & $\boldsymbol{C R}$ & $\boldsymbol{P}$ & $\boldsymbol{R}^{2}$ \\
\cline { 3 - 7 } $\begin{array}{c}\text { Purchase_I } \\
\text { ntention }\end{array}$ & $<---$ & $\begin{array}{c}\text { Luxury_B } \\
\text { rand }\end{array}$ & 0,910 & 0,722 & 0,127 & 7,175 & 0,000 & 0,521 \\
\hline
\end{tabular}

Sumber: Hasil Pengolahan Data, 2019.

(Menggunakan Software IBM SPSS AMOS versi 24.0 for Windows) 
Journal of Business Education | Volume 4, Number 3, December 2019, page. 54-66

Hasil uji kebermaknaan terhadap estimasi koefisien jalur pada model signifikan pada tingkat kesalahan $5 \%$ yang ditunjukkan dengan nilai $\mathrm{CR}=7,175>1,96$ atau nilai $\mathrm{P}$-value memiliki nilai $<0,05$.

\section{Kecocokan Keseluruhan Model (Overall Model Fit)}

Uji kecocokan keseluruhan model dilakukan untuk mengevaluasi secara umum derajat kecocokan atau goodness of fit. Dalam pengujian Goodness of fit, kriteria penilaian dapat dilakukan sesuai pendapat dari berbagai ahli.

Adapun indikator pengujian goodness of fit dan batas nilai (cut-off value) yang digunakan dalam kesesuaian model penelitian ini ditampilkan pada Tabel 8 berikut.

TABEL 8

HASIL PENGUJIAN GOODNESS OF FIT

\begin{tabular}{|c|c|c|c|c|}
\hline No & Goodness-of-Fit Measures & Cut-off value & Hasil & $\begin{array}{c}\text { Evaluasi } \\
\text { Model }\end{array}$ \\
\hline \multicolumn{5}{|c|}{ Absolute Fit Measures } \\
\hline & Statistic Chi-square $\left(X^{2}\right)$ & & & \\
\hline 1 & $\begin{array}{l}(\mathrm{CMIN}) \\
(\mathrm{df}=26)\end{array}$ & $\chi^{2}$ hit $<\chi^{2}$ Tabel $(38,885)$ & 23,449 & Good Fit \\
\hline 2 & $\mathrm{CMIN} / \mathrm{DF}$ & $<2$ & 0,902 & Good Fit \\
\hline 3 & Goodness of Fit Index (GFI) & $\begin{array}{c}\text { GFI } \geq 0.90 \text { good fit }, 0.80 \leq \\
\text { GFI }<0.90 \text { marginal fit }\end{array}$ & 0.974 & Good Fit \\
\hline 4 & $\begin{array}{l}\text { Root Mean Square Error of } \\
\text { Approximation (RMSEA) }\end{array}$ & $\leq 0.08$ & 0.000 & Good Fit \\
\hline 5 & $\begin{array}{l}\text { Root Mean Square Residual } \\
\text { (RMSR) }\end{array}$ & $-0,4<\mathrm{RMSR}<0,4$ & 0,121 & Good Fit \\
\hline \multicolumn{5}{|c|}{ Incremental Fit Measures } \\
\hline 1 & Trucker-Lewis Index (TLI) & $\begin{array}{c}\mathrm{TLI} \geq 0.90 \text { good fit, } 0.80 \leq \\
\mathrm{TLI}<0.90 \text { marginal fit }\end{array}$ & 1,003 & Good Fit \\
\hline 2 & $\begin{array}{l}\text { Adjusted Goodness of Fit } \\
\text { Indices (AGFI) }\end{array}$ & $\geq 0.90$ & 0,956 & Good Fit \\
\hline 3 & Normed Fit Index (NFI) & $\begin{array}{c}\mathrm{CFI} \geq 0.90 \text { good fit }, 0.80 \leq \\
\mathrm{CFI}<0.90 \text { marginal fit }\end{array}$ & 0,969 & Good Fit \\
\hline 4 & Comparative Fit Index (CFI) & $\begin{array}{c}\mathrm{CFI} \geq 0.90 \text { good fit, } 0.80 \leq \\
\mathrm{CFI}<0.90 \text { marginal fit }\end{array}$ & 1,000 & Good Fit \\
\hline \multicolumn{5}{|c|}{ Parsimonius Fit Measures } \\
\hline 1 & $\begin{array}{c}\text { Parsimonious Normed Fit } \\
\text { Index (PNFI) }\end{array}$ & $\begin{array}{c}\text { Semakin tinggi semakin baik, } \\
\text { dibandingkan dengan } \\
\text { alternatif model }\end{array}$ & 0.700 & Good Fit \\
\hline 2 & $\begin{array}{c}\text { Parsimonious Goodness of fit } \\
\text { Index (PGFI) }\end{array}$ & PGFI $<$ GFI & 0.563 & Good Fit \\
\hline
\end{tabular}

Sumber: Hasil Pengolahan Data, 2019.

(Menggunakan Software IBM SPSS AMOS versi 24.0 for Windows)

Hasil Pengujian Goodness of Fit yang diperoleh menunjukkan models ecara keseluruhan fit. Ukuran Goodness of Fit sesuai dengan rekomendasi dan lebih besar dari cut off value. 
Goodness of fit pada Tabel 4.32 menunjukkan model dilihat dari nilai chi-square baik atau memenuhi ukuran kesesuaian model (nilai chi-square sebesar 23,449 lebi kecil dari nilai table chi-square 38,885 dengan tingkat signifikansi lebih besar dari 0,05. Model penelitian memiliki nilai CMIN/DF, GFI, NFI dan RMSEA yang menunjukkan tingkat kesesuaian yang baik. Nilai AGFI 0,956 $\geq 0,90$ (good fit), nilai TLI $1,003 \geq 0.90$ (good fit).

Pada uji goodness of fit model penelitian ini, nilai kriteria GOF telah memenuhi syarat dengan memiliki nilai good fit. Sehingga dapat dikatakan bahwa model ini dinyatakan layak secara untuk dipergunakan sebagai alat dalam mengkonfirmasi teori yang telah dibangun berdasarkan data observasi yang ada atau dapat dikatakan bahwa model ini sudah fit.

\section{Respesifikasi Model (Model Respesification)}

Tahap ini berkaitan dengan respesifikasi model berdasarkan atas hasil uji kecocokan tahap sebelumnya. Pelaksanaan respesifikasi sangat tergantung pada strategi pemodelan yang akan digunakan. Pada tahapan uji goodness of fit model sebelumnya hasil sudah menunjukkan model yang sudah good fit, maka pada penelitian ini tidak lagi dilakukan tahapan respesifikasi lebih lanjut.

\section{KESIMPULAN DAN SARAN}

Kesimpulan dari penelitian ini adalah bahwa luxury brand dan purchase intention berada pada kondisi yang baik luxury brand memiliki pengaruh yang positif dan signifikan terhadap luxury brand pada anggota komunitas iDevice Indonesia. Hal tersebut ditunjukan dengan besarnya nilai critical ratio yang jauh lebih besar dari batas minimal yang menyebabkan $\mathrm{H} 0$ ditolak. Artinya luxury brand dapat menjelaskan purchase intention secara positif dan signifikan. Hal ini berarti semakin baik pengelolaan luxury brand yang diberikan perusahaan semakin baik pula purchase intention yang didapatkan dari pelanggan.

\section{E. Pengujian Hipotesis}

Pengujian hipotesis dilakukan dengan menggunakan $t$-value dengan tingkat signifikansi 0,05 dan derajat kebebasan sebesar n (sampel). Nilai $t$-value dalam program IBM SPSS AMOS versi 24 merupakan nilai Critical Ratio (C.R.). Apabila nilai Critical Ratio (C.R.) $\geq 1,96$ atau nilai probabilitas $(\mathrm{P}) \leq 0,05$ maka $\mathrm{H}_{0}$ ditolak (hipotesis penelitian diterima). Kriteria penerimaan atau penolakan hipotesis utama pada penelitian ini dapat ditulis sebagai berikut:

$\mathrm{H}_{0}: \gamma=0$; Tidak terdapat pengaruh antara Luxury Brand dengan Purchase Intention

$\mathrm{H}_{1}: \gamma \neq 0$; Terdapat pengaruh antara Luxury Brand dengan Purchase Intention

Berdasarkan hasil pengolahan data model SEM dengan software AMOS 24 didapatkan nilai C.R dari variabel Luxury Brand ke Purchase Intention sebesar 7,175 dengan probability sangat kecil $(0,000)$. Nilai $C R \geq 1,96$ sehingga $\mathrm{H}_{0}$ ditolak dan $\mathrm{H}_{1}$ diterima, artinya terdapat pengaruh Luxury Brand terhadap Purchase Intention.

Adapun besaran pengaruh dari Luxury Brand terhadap Purchase Intention bernilai positif sebesar 0,910 terlihat dari output total effect. Dengan nilai ini dapat dikatakan terdapat pengaruh positif yang signifikan antara Luxury Brand terhadap Purchase Intention sebesar 0,910 satuan nilai.

.Penulis merekomendasikan perusahaan pada industri smartphone untuk terus meningkatkan kinerja dalam mengelola luxury brand. Pengelolaan luxury brand yang baik dapat mempertahankan pelanggan untuk tidak berpindah pada merek lainnya, sehingga dapat menumbuhkan purchase intention pelanggan atas suatu perusahaan.

\section{DAFTAR PUSTAKA}

Agrebi, S., \& Jallais, J. (2015). Journal of Retailing and Consumer Services Explain the intention to use smartphones for mobile shopping. Journal of Retailing and Consumer Services, 22, 16-23. 
https://doi.org/10.1016/j.jretconser.2014.09 .003

Ardelia. (2017). Pengaruh Brand Credibility Dan Brand Prestige Terhadap Persepsi Kualitas Dan Minat Beli ( Survei pada konsumen kosmetik merek Chanel ). Administrasi Bisnis, 50(3), 9-18.

Azira, Zaharah, S., Kuan, L., Abas, N., \& Meriam, S. (2016). Factors Influencing Purchasing Intention of Smartphone among University Students. Procedia Economics and Finance, 37(16), 245-253. https://doi.org/10.1016/S22125671(16)30121-6

Bedi, S. S. (2017). Understanding Web Experience and Perceived Web Enjoyment as Antecedents of Online Purchase Intention, 18(2), 1-13. https://doi.org/10.1177/0972150916668614

Bian, Q., \& Forsythe, S. (2012). Purchase intention for luxury brands: A cross cultural comparison. Journal of Business Research, 65(10), 1443-1451. https://doi.org/10.1016/j.jbusres.2011.10.0 10

Chen, C. (2018). Product attributes and purchase intention for smartphones: a moderated mediation model Hsian-Ming Liu * Bao-Yi Ann. Product Attributes and Purchase Intention for Smartphones, 16(1), 1-23.

Chiang, C., \& Jang, S. S. (2008). The Effects of Perceived Price and Brand Image on Value and Purchase Intention: Leisure Travelers $\hat{a} €^{\mathrm{TM}}$ Attitudes Toward Online Hotel Booking The Effects of Perceived Price and Brand Image on Value and Purchase Intention: Leisure Travelers ' Attitudes Towar, (October 2014), 37-41. https://doi.org/10.1300/J150v15n03

Collange, V. (2015). The impact of brand name substitution on product evaluation and purchase intention, 23(2), 1-17.

Das, G. (2017). Impact of Social Influence and Green Consumption Values on Purchase Intention of Organic Clothing: A Study on Collectivist Developing Economy. Global Business, 18(2), 1-16. https://doi.org/10.1177/0972150916668620

Echo Huang. (2012). Online experiences and virtual goods purchase intention, 22(3), 252-274. https://doi.org/10.1108/1066224121123564 4

El-baz, D. (2016). Electronic word of mouth effects on consumers brand attitudes, brand image and purchase intention: an empirical study in Egypt. Electronic Word of Mouth Effects on Consumers 'Brand Attitudes , Brand Image and Purchase Intention: An Empirical Study in Egypt, 7(5), 268-276.

Favre, E. (2007). Online Auction Houses: How Trademark Owners Protect Brand Integrity Against Counterfeiting. Journal of Law and Policy, 15(1), 165-210. https://doi.org/10.1525/sp.2007.54.1.23.

Gana, M. A., \& Koce, H. D. (2016). Mobile Marketing: The Influence of Trust and Privacy Concerns on Consumers ' Purchase Intention. Mobile Marketing : The Influence of Trust and Privacy Concerns on Consumers ' Purchase Intention, 8(2), 121127. https://doi.org/10.5539/ijms.v8n2p121

Haba, H. F. (2017). Factors Leading to Consumer Perceived Value of Smartphones and its Impact on Purchase Intention. Factors Leading to Consumer Perceived Value of Smartphones and Its Impact on Purchase Intention, 9(1), 42-71.

Jalilvand, M. R., \& Samiei, N. (2012). The effect of electronic word of mouth on brand image and purchase intention An empirical study in the automobile, 460-476. https://doi.org/10.1108/0263450121123194 6

Khan, I., \& Rahman, Z. (2014). Influence of Experiential Marketing on Customer Purchase Intention: A Study of Passenger Car Market, 39(3), 319-328. https://doi.org/10.1177/0258042X1557241 1

Kim, L. H., \& Leong, J. K. (2014). The Effect of Perceived Risk on Purchase Intention in Purchasing Airline Tickets Online The Effect of Perceived Risk on Purchase Intention in Purchasing Airline Tickets Online. Journal of Hospitality \& Leisure Marketing, (August), 37-41. https://doi.org/10.1300/J150v13n02

Ko, S. B. (2017). Predictors of purchase intention toward green apparel products A crosscultural investigation in the. Journal of 
Journal of Business Education | Volume 4, Number 3, December 2019, page. 54-66

Fashion Marketing and Management, 21(1), 1361-2026. https://doi.org/10.1108/JFMM-07-20140057

Lassar, W., Mittal, B., \& Sharma, A. (1995). Measuring customer-based brand equity. Journal of Consumer Marketing, 12(4), 1119.

Lee, M. C. C., Chen, M., \& Lee, C. (2015). The impacts of green claims on coffee consumers , purchase intention, 117(1), 195-209. https://doi.org/10.1108/BFJ-072013-0196

Liu, M. T. (2011). Relations among attractiveness of endorsers , match-up , and purchase intention in sport marketing in China. https://doi.org/10.1108/0736376071082294 5

Mccall, M., \& Lynn, A. (2015). Journal of Foodservice The Effects of Restaurant Menu Item Descriptions on Perceptions of Quality, Price, and Purchase Intention. Journal of Foodservice Business Research, 11(4), 439-445. https://doi.org/10.1080/1537802080251985 0

Pan, M. (2013). Antecedent of purchase intention : online seller reputation, product category and surcharge, 23(4), 507-522. https://doi.org/10.1108/IntR-09-2012-0175

Phau, I., \& Teah, M. (2009). Devil wears ( counterfeit ) Prada : a study of antecedents and outcomes of attitudes towards counterfeits of luxury brands. Journal of Consumer Marketing, 26(1), 15-27. https://doi.org/10.1108/0736376091092701 9

Plavini Punyatoya. (2015). Effect of perceived brand environment-friendliness on Indian consumer attitude and purchase intention. Marketing Intelligence \& Planning, 33(3), 258-275.

Sujata, J., Roy, A., Thakkar, D., Banik, A., Arora, G. D., \& Parashar, P. (2015). Conceptual Paper on Factors Afecting the Attitude of Senior Citizens towards Purchase of Smartphones. Conceptual Paper on Factors Afecting the Attitude of Senior Citizens towards Purchase of Smartphones, 8(February), 83-89.

Wang, Y., Wiegerinck, V., Krikke, H., \& Zhang,
H. (2013). Understanding the purchase intention towards remanufactured product in closed-loop supply chains An empirical study in China. Journal of Physical Distribution \& Logistics Management, 43(10), 1-24. https://doi.org/10.1108/IJPDLM-01-20130011

Wogalter, M. S., Kalsher, M. J., \& Litynski, D. M. (1996). Influence of Food Label Quantifier Terms on Connoted Amount and Purchase Intention, 385-389.

Yvonne, A., \& Kristaung, R. (2013). Metodologi Penelitian Bisnis dan Akuntansi. Jakarta: Dian Rakyat. 